\title{
Pivotal role of the muscle-contraction pathway in cryptorchidism and evidence for genomic connections with cardiomyopathy pathways in RASopathies
}

Carlo V Cannistraci ${ }^{1,2,3^{*}+}$, Jernej Ogorevc ${ }^{4 \dagger}$, Minja Zorc ${ }^{4 \dagger}$, Timothy Ravasi ${ }^{1}$, Peter Dovc ${ }^{4}$ and Tanja Kunej ${ }^{4^{*}}$

\begin{abstract}
Background: Cryptorchidism is the most frequent congenital disorder in male children; however the genetic causes of cryptorchidism remain poorly investigated. Comparative integratomics combined with systems biology approach was employed to elucidate genetic factors and molecular pathways underlying testis descent.

Methods: Literature mining was performed to collect genomic loci associated with cryptorchidism in seven mammalian species. Information regarding the collected candidate genes was stored in MySQL relational database. Genomic view of the loci was presented using Flash GViewer web tool (http://gmod.org/wiki/Flashgviewer/). DAVID Bioinformatics Resources 6.7 was used for pathway enrichment analysis. Cytoscape plug-in PiNGO 1.11 was employed for protein-network-based prediction of novel candidate genes. Relevant protein-protein interactions were confirmed and visualized using the STRING database (version 9.0).

Results: The developed cryptorchidism gene atlas includes 217 candidate loci (genes, regions involved in chromosomal mutations, and copy number variations) identified at the genomic, transcriptomic, and proteomic level. Human orthologs of the collected candidate loci were presented using a genomic map viewer. The cryptorchidism gene atlas is freely available online: http://www.integratomics-time.com/cryptorchidism/. Pathway analysis suggested the presence of twelve enriched pathways associated with the list of 179 literature-derived candidate genes. Additionally, a list of 43 network-predicted novel candidate genes was significantly associated with four enriched pathways. Joint pathway analysis of the collected and predicted candidate genes revealed the pivotal importance of the muscle-contraction pathway in cryptorchidism and evidence for genomic associations with cardiomyopathy pathways in RASopathies.

(Continued on next page)
\end{abstract}

\footnotetext{
*Correspondence: kalokagathos.agon@gmail.com; tanja.kunej@bf.uni-lj.si

${ }^{\dagger}$ Equal contributors

${ }^{1}$ Integrative Systems Biology Laboratory, Biological and Environmental Sciences and Engineering Division, Computer, Electrical and Mathematical Sciences and Engineering Division, Computational Bioscience Research Center, King Abdullah University for Science and Technology (KAUST), Thuwal, Saudi Arabia

${ }^{4}$ Department of Animal Science, Biotechnical Faculty, University of Ljubljana, Domzale, Slovenia

Full list of author information is available at the end of the article
} 


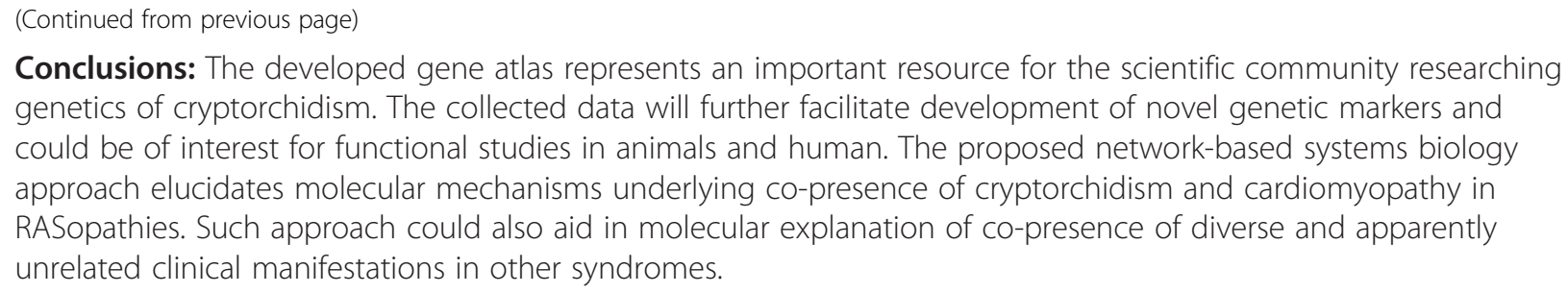

Keywords: Cryptorchidism, Muscle-contraction pathway, Cardiomyopathy, Comparative integratomics, Protein-protein interactions, Systems biology, Undescended testes, RASopathy

\section{Background}

Cryptorchidism (CO) is the most frequent congenital disorder in male children (2-4\% of full-term male births) and is defined as incomplete descent of one (unilateral) or both (bilateral) testes and associated structures. Cryptorchidism has a potential effect on health; defects in testes descent usually cause impaired spermatogenesis, resulting in reduced fertility and increased rates of testicular neoplasia, and testicular torsion (reviewed in [1]). Cryptorchidism is common in human, pigs, and companion animals $(2-12 \%)$ but relatively rare in cattle, and sheep $(\leq 1 \%)[2]$.

Testicular descent is a complex series of events which requires concerted action of hormones, constitutive mechanisms, and the nervous system. In most species, including human, the complete descent of testes usually occurs prenatally, while in some (e.g. dogs), postnatally. Beside environmental factors like endocrine disruptors, $\mathrm{CO}$ is at least in part determined by genetic causes (chromosome or gene mutations), and is often a common feature of different syndromes. For example, Klinefelter syndrome and mutations in INSL3 gene have already been recognized as a cause of $\mathrm{CO}$ in some cases [3].

The comparative knowledge attained through study of animal models has been of great importance in understanding complex disease etiology, suggesting several candidate genes involved also in the pathogenesis of human diseases [4]. Therefore, the use of comparative genomics approach, integrating and cross-filtering the available knowledge from different species seems highly justified. Different animal models for CO exist; for example natural mutants or transgenic mice, rat, rabbit, dog, pig and rhesus monkeys are used to elucidate the role of different factors involved in $\mathrm{CO}$ [5]. Based on mouse knock-out models from Mouse Genome Informatics (MGI) database, several genes appear as possible candidates (AR, HOX genes, INSL3, RXFP2, and WT1). Additionally, the technological progress in the last years enabled the use of high-throughput omics-information, at coding (DNA), expression (RNA), and proteomic level. This technological revolution creates a vast amount of data, which increases the need for application of bioinformatics tools that are able to connect omics data with phenotype and enable search for overlapping pathogenetic mechanisms in different genetic diseases [6]. However, this existing technology hasn't been significantly employed in human $\mathrm{CO}$ research on a genome and transcriptome-wide scale; to date only one genomewide expression study has been performed in rat [7].

Integratomics represents a novel trend in the omicsresearch and is based on the integration of diverse omics-data (genomic, transcriptomic, proteomic, etc.), regardless of the study approach or species [8-10]. High genetic homology between mammals and the availability of well annotated genomes from different species allows the assembled data to be presented in a form of a comparative genomic view, displaying candidate genes as a single species orthologs.

Information extracted from diverse and methodologically focused studies are often fragmented and controversial. To overcome this problem we integrated the collected data, using a holistic (map-driven) approach, and developed freely available interactive genomic visualization tool. Such map-based approach allows identification and prioritization of candidate genes [11] based on a number of literature sources (references), genomic position, and pathway analyses, employing all currently available knowledge in different species. However, extrapolating the gained knowledge from one species to another is often difficult due to different anatomical and physiological characteristics, which should be considered when comparing pathology of the disease in different species.

To identify genetic factors potentially involved in $\mathrm{CO}$ pathogenesis in human we 1) applied comparative integratomics approach and assembled the database of all $\mathrm{CO}$-associated genomic loci reported in the literature, regardless of the study approach and species, 2) presented the loci on a genomic map as human orthologs, and 3) prioritized the collected data using systems biology approach. The collected candidate genes were classified in corresponding biological pathways and the most significant CO-enriched pathways were proposed. Such classification of candidate genes allowed us to prioritize biological pathways (characterized by genes involved in the 
pathogenesis of $\mathrm{CO}$ ), which revealed importance of several pathways (for example muscle contraction mechanisms) that may also play a role in the pathogenesis of other clinical features distinctive for different syndromes often concurrent with $\mathrm{CO}$. In order to additionally illuminate the $\mathrm{CO}$-associated pathways we performed a network-based protein-protein interaction analysis, which resulted in prediction of 43 additional $\mathrm{CO}$ candidate genes.

\section{Methods}

In search for $\mathrm{CO}$ associated candidate loci seven different research approaches were considered: (i) chromosomal abnormalities associated with $\mathrm{CO}$, (ii) copy number variations, (iii) clinical syndromes with known genetic mutations that feature $\mathrm{CO}$, (iv) transgenes and knock-outs that result in $\mathrm{CO}$ associated phenotypes, (v) association studies/mutation screening that show association between sequence variation/mutation screening and $\mathrm{CO}$, (vi) expression patterns associated with $\mathrm{CO}$, and (vii) candidates associated with $\mathrm{CO}$ at proteomic level.

\section{Data mining}

We reviewed the literature published up to 9/2012 searching for the relevant publications through PubMed (http://www.ncbi.nlm.nih.gov/pubmed/) and Web of Science (http://isiknowledge.com) using key phrases: genetics, gene candidates, cryptorchidism, testicular descent, undescended testes, male infertility, QTL, microarray, association, microRNA, non-coding RNA, epigenetic, reproduction, and assisted reproduction. CO-associated candidate genes from different sources and species were retrieved from the literature search. Human clinical syndromes that may cause or feature $\mathrm{CO}$ were retrieved from Online Mendelian Inheritance in Man (OMIM) database (http://www.ncbi.nlm.nih.gov/sites/entrez?db=omim) and Disease database (http://www.diseasesdatabase.com/). The data for CO-related experiments on mouse models were retrieved from the Mouse Genome Informatics (MGI) database (http://www.informatics.jax.org/). Human orthologs for the $\mathrm{CO}$ associated genes were extracted from the MGI database, which contains information about mammalian ortholog genes for different species. Overlap analysis of the $\mathrm{CO}$ candidate genes with genomic regions involved in chromosome mutations was performed using data retrieved from Ensembl via BioMart data mining tool.

\section{Database implementation}

$\mathrm{CO}$-associated candidate genes database is a web resource, which provides integrated and curated information on molecular components involved in the pathogenesis of $\mathrm{CO}$. Information regarding collected $\mathrm{CO}$ associated candidate genes has been stored in relational MySQL database, which is publicly available for search, data entry and update at http://www.integratomics-time. com/cryptorchidism/. Search interface enables users to find specific $\mathrm{CO}$-associated candidate genes based on the number of criteria. Online data entry interface enables users to update or submit new $\mathrm{CO}$-associated candidate genes.

\section{Genomic view of the $\mathrm{CO}$ associated loci}

Overview of the chromosomal locations of $\mathrm{CO}$ associated loci is graphically represented in genomic view, as previously described [12]. It is possible to visualize the literature-collected and network-predicted $\mathrm{CO}$ genes on the same genomic view or separately. Genomic view is visible through the web-based interactive visualization tool Flash GViewer (http://gmod.org/wiki/ Flashgviewer/), which was developed by the GMOD project.

\section{Pathway and network analysis}

In the first pathway analysis we considered human orthologs of the literature-collected candidate genes (179 genes). DAVID Bioinformatics Resources 6.7 [13] was employed for the enrichment (overrepresentation) analysis. The background for the analysis was defined using the 179 candidate genes plus their first neighbours (5018 proteins) selected in the human protein-protein interaction network (PPIN). The result of the enrichment analysis was obtained using Bonferroni multiple test correction and a p-value significant threshold of 0.01 . The human PPIN was obtained by fusion of the following human networks: IRefIndex [14], Chuang et al. article [15], Ravasi et al. article [16], ConsensusPathDB [17].

A new cohort of 43 candidate genes was predicted using PiNGO 1.11 [18]. PiNGO is a tool designed to find candidate genes in biological networks and it is freely provided as a plug-in for Cytoscape 2.8 [19], which is an open source software platform for visualizing and integrating molecular interaction networks. PiNGO predicts the categorization of a candidate gene based on the annotations of its neighbors, using enrichment statistics. In our analysis we quested which first-neighbour-genes significantly interact with the original cohort of 179 literature-collected genes in the human PPIN. We adopted: hypergeometric statistical test, Bonferroni multiple testing correction and $\mathrm{p}$-value significant threshold of 0.01 . The cohort of 43 network-predicted genes resulted strongly significant (Bonferroni p-value $<0.0095$ ) for being new candidate genes.

In order to evaluate the importance of this new cohort of 43 candidate genes we performed the pathway analysis according to the procedure already described for the 179 literature-collected candidate genes. 
Finally, in order to investigate the biological relations between the 179 literature-collected and 43 networkpredicted genes, we repeated the pathway analysis in DAVID (using the same procedure previously described) considering the $222(179+43)$ candidate genes. The background for the analysis was defined using the 222 candidate genes plus their first neighbours in the human PPIN. In addition, we visualized the protein-protein interactions occurring between the genes present in at least two pathways using the STRING database (version 9.0) [20] and selecting only interactions with high confidence score.

\section{Genetic variability of candidate genes}

Genetic variability for the most promising $\mathrm{CO}$ candidate genes was extracted from the Ensembl database (http://www.ensembl.org/). Probably damaging genetic variations were predicted by PolyPhen-2, version 2.1.0, provided by Ensembl database. Putative polymorphic miRNA target sites in candidate genes were obtained from Patrocles database (http://www.patrocles.org/) [21].

\section{Results and discussion}

Extensive literature mining was performed resulting in 217 collected candidate loci (chromosome regions and genes) reported to be involved in $\mathrm{CO}$ in human or/and animals. The generated database served as the foundation for the development of freely available interactive genomics viewer designed to integrate multi-species data from various research approaches. Enriched biological pathways and 43 additional $\mathrm{CO}$ candidate genes were suggested, based on protein-protein interaction network (PPIN) analysis. The workflow of the study is presented in the Figure 1.

\section{Collection of the cryptorchidism associated loci from the literature}

The collected data incorporates genomic loci associated with cryptorchidism by seven different types of research approaches (chromosomal mutations, copy number variations, clinical syndromes, transgenes and knock-outs, association studies/mutation screening, transcriptomic/expression studies, and proteomic studies). The collected

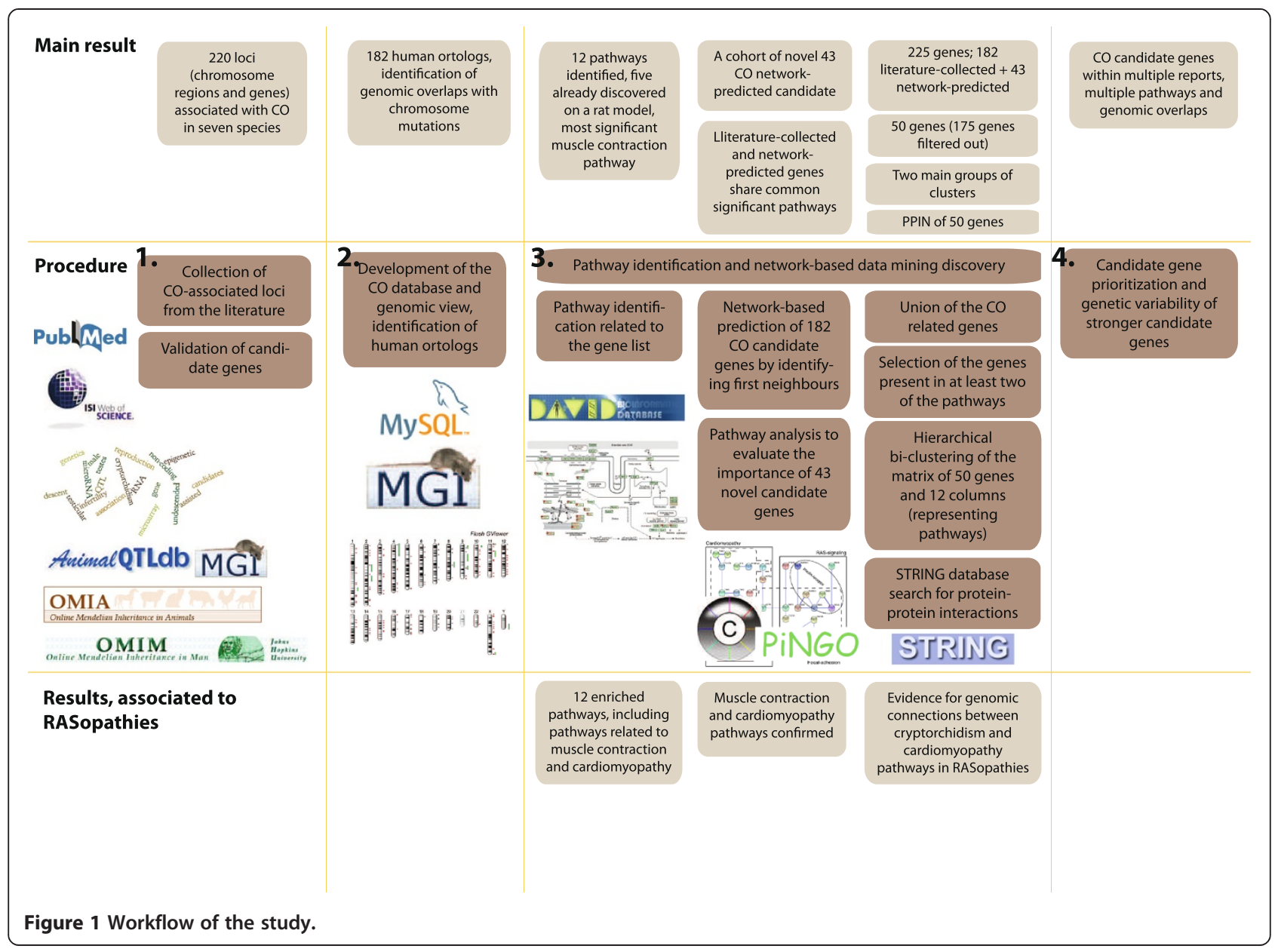


data originates from seven different species (human, cattle, horse, sheep, dog, rat, and mouse) (Table 1). The collected CO data is available in Additional file 1: Table S1, Additional file 2: Table S2, Additional file 3: Table S3, Additional file 4: Table S4 and Additional file 5: Table S5 and include physical locations of the candidate loci in human and species of origin.

\section{Chromosomal aberrations and copy number variations}

We reviewed studies reporting 32 different chromosomal mutations including numerical and structural aberrations associated with cryptorchidism [22-33]. Additionally, two de novo copy number variations (CNVs) - microduplications were found to be associated with $\mathrm{CO}$ using array-based comparative genomic hybridization (aCGH) [34]. The collected data is available in Additional file 1: Table S1.

\section{Clinical syndromes}

Studies of complex disease traits can be facilitated by analysis of the molecular pathways represented by genes responsible for monogenic syndromes that also exhibit these traits [7,35]. There are over 200 different human syndromes with known molecular basis in OMIM database that feature "cryptorchidism" or "undescended testis" as a possible feature in their clinical synopsis. Since cryptorchidism phenotype prevalence is low in some syndromes, and could only occur coincidentally, it is difficult to justify association of syndrome causative genes with a particular phenotype.

To collect CO candidate genes (Additional file 2: Table S2) we obtained list of syndromes from the literature [4,36,37], OMIM and Diseases database ("may be caused or feature") and then further examined phenotype-gene relationships and clinical features for each of the syndromes. Only

Table 1 The summary of $\mathrm{CO}$ associated candidate loci

\begin{tabular}{ll}
\hline Locus type / study approach & Number of loci \\
\hline DNA level & 32 \\
Chromosomal aberrations & 2 \\
Copy number variants (CNVs) & 42 \\
Clinical syndromes & 40 \\
Knock-out and transgenic experiments & 12 \\
Association studies & \\
RNA level & 112 \\
Expression study & \\
Protein level & 1 \\
Injection of exogenous protein & $217^{*}$ \\
Total & * Unique loci (individual locus/gene reported by multiple studies was counted \\
only once).
\end{tabular}

syndromes where cryptorchidism is present as a regular feature, described in multiple clinical cases, and where gene(s) causing the syndrome is/are known were included.

\section{Transgenes and knock-outs}

From the Mouse Genome Informatics (MGI) database and the literature [38-42] we retrieved 39 mouse and one rat $\mathrm{KO}$ and transgenic experiments that result in phenotypes associated with CO (Additional file 3: Table S3).

\section{Association studies/mutation screening}

Nine genes (AR, BMP7, ESR1, HOXA10, INSL3, KISS1R, NR5A1, RXFP2, and TGFBR3) in human [43-59], INSL3 in sheep [60] and $\operatorname{dog}$ [61], and COL2A1 in dog [62] showed positive association between sequence polymorphisms/mutations and CO susceptibility (Additional file 4: Table S4). In the case of androgen receptor $(A R)$ gene Ferlin et al. [45] found no difference between the numbers of CAG and GGC repeats, resulting in variable lengths of PolyGln/PolyGly in the $A R$ gene and cryptorchidism; however, it has been proposed that a particular combination of the PolyGln/PolyGly polymorphisms may be linked to $\mathrm{CO}$. In some cases opposing results have been found; for example, no association between the sequence polymorphisms and $\mathrm{CO}$ have been found for the genes ESR1 [63-65], INSL3 [66-68], HOXA10 [69], and RXFP2 [70]. The $L H C G R$ has been excluded as a $C O$ candidate gene in an association study in men [71], although $\mathrm{KO}$ of this gene in mice showed cryptorchid phenotype (MGI) and is causative gene of Leydig cell hypoplasia-a syndrome that features $\mathrm{CO}$ as one of the clinical signs (OMIM). In addition, $\mathrm{Y}$ chromosome microdeletions have been found to be present in patients with $\mathrm{CO}$, but are not likely to be a common etiological cause of $\mathrm{CO}$ [72-74].

\section{Expression patterns}

There are several studies comparing expression profiles in testes between cryptorchid and normal males investigating the resulting effects of but not causes for development of CO (e.g. [75,76]). To our knowledge, there is only one microarray study that analyzed transcript profiles in gubernaculum during normal and abnormal testicular descent and reported 3589 differentially expressed genes between inherited cryptorchydism orl rats and a control group [7]. We included a subset of 112 promising candidate genes to our candidate gene list that were selected by the authors of the study based on expression levels, inclusion in specific pathways of interest and/or previous reports showing association with cryptorchidism (Additional file 5: Table S5).

\section{Protein level}

Hutson et al. (1998) [77] investigated the effect of exogenous calcitonin gene-related peptide (CGRP) in 
neonatal pigs. They found that exogenous CGRP, in pigs also known as calcitonin gene-related peptide $B$ (CALCB), stimulated migration of inguinal testes that had been arrested in the line of descent, while ectopic testes did not respond. The results support the role for this protein in testicular descent. However, mutation screening performed by Zuccarello et al. (2004) [78] failed to confirm CGRP (in human also known as $C A L C A$ ) pathway genes as a major players in human sporadic $\mathrm{CO}$.

\section{Development of the CO database and genomic viewer}

The CO-associated loci, obtained by comparative integratomics approach, were assembled into a freely accessible database available at http://www.integratomicstime.com/cryptorchidism/. The curated database is open for public data entry. Researchers are invited to submit new cryptorchidism candidate genes from their research or other publications by filling data entry form on our web site. The collected loci from human and animal species were presented as genomic view for human orthologs (in a form of a human genomic view) (Figure 2).

Some candidate genes have been associated with $\mathrm{CO}$ by multiple independent literature reports in multiple species. For example, twenty genes $(A M H, A M H R 2, A R$, ARID5B, BMP7, EPHA4, ESR1, FGFR2, HOXA10, HRAS, INSL3, LHCGR, MAP2K1, MSX1, NR5A1, RXFP2, SOS1, TNNI2, TNNT3, and WT1) have been associated with

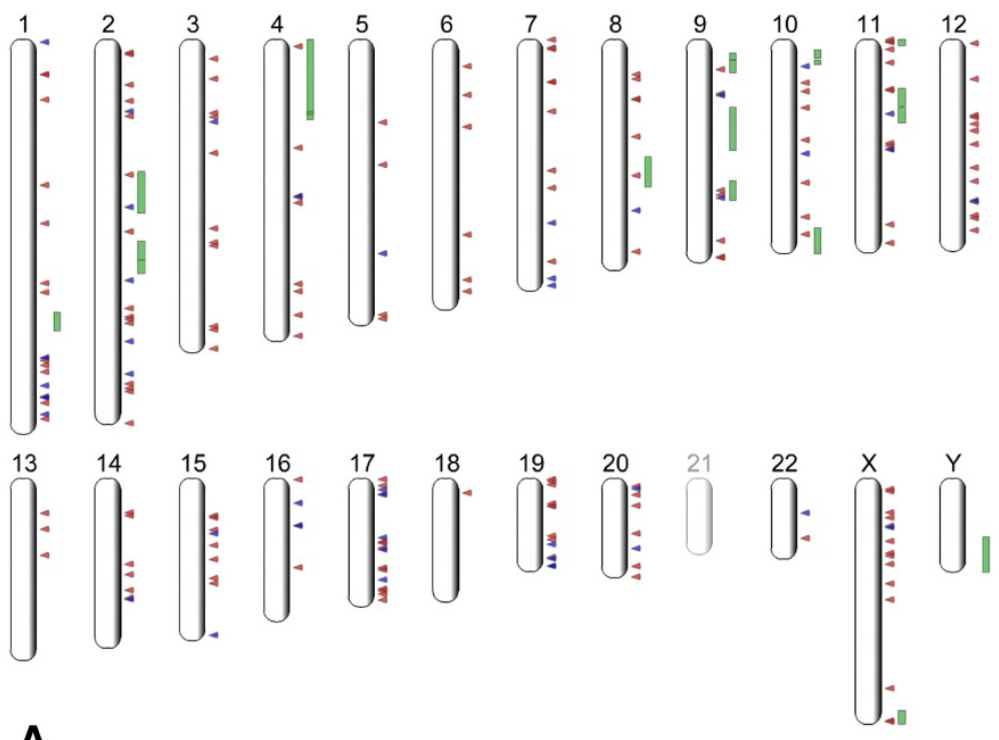

A $46, X X, t(9 ; 11)(p 22 ; p 15.5)$

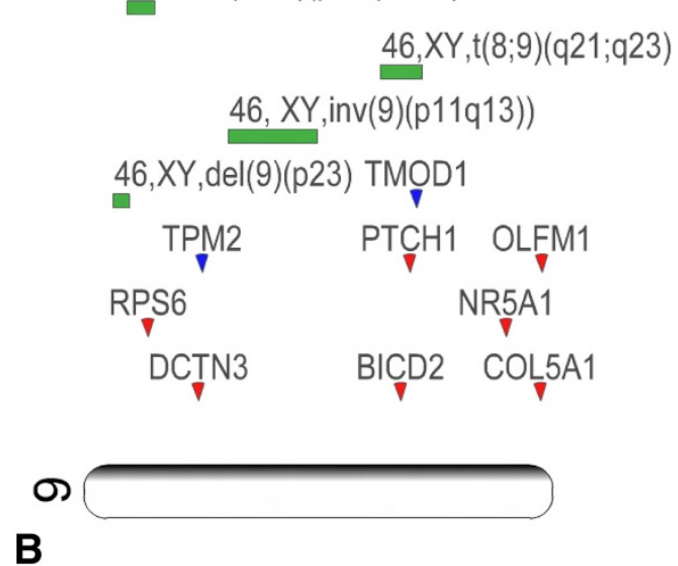

Figure 2 Genomic view of the cryptorchidism candidate genes. A. Genomic view of the literature-collected (red) and network-predicted (blue) $\mathrm{CO}$ associated candidate loci presented as human orthologs. The view includes syndromes with known genetic mutations that feature $\mathrm{CO}$, mouse transgenic and knock-out experiments, chromosomal abnormalities, genes tested for association with CO, genes with expression patterns associated with $\mathrm{CO}$, and genes associated with $\mathrm{CO}$ on proteomic level. Loci are placed at approximate positions on chromosome map. B. Enlargement of the chromosome 9 . 
$\mathrm{CO}$ in at least two independent studies using different study approaches (Table 2). These genes are denoted in bold in the online database (http://www.integratomicstime.com/cryptorchidism/candidate_genes/).

The CO associated loci mapped to all human chromosomes, except HSA21. Genomic distribution of the selected loci revealed several overlapping areas between the candidate loci. Overlaps between structural chromosomal mutations and candidate genes can be observed in Figure 2 or by using interactive genomic view available on the website (http://www.integratomics-time.com/cryptorchidism/ genomic_view/). Genomic regions involved in chromosome mutations on chromosomes 2, 4, 8, 9, 11, and X [22-33] overlapped with 13 literature-collected candidate genes: CAPG, MSX1, E2F5, PTCH1, BICD2, RPS6, FGFR2, HRAS, PAX6, WT1, TNNI2, TNNT3, FLNA, and MECP2. For instance, a breakpoint on 11p15.5 overlapped with three $\mathrm{CO}$ candidate genes: HRAS, TNNI2, and TNNT3. Additionally, in some cases two regions involved in chromosome mutations overlapped; duplication on position $4 \mathrm{p}$ overlapped with $M S X 1$ gene and the region involved in chromosomal translocation on position 4p12. Interestingly, three network-predicted candidate genes, FHL2, TMOD1 and $M Y B P C 3$, also overlapped with genomic regions involved in the chromosome mutations.

\section{Pathway identification and network-based data mining discovery \\ Pathway analysis of the cryptorchidism associated candidate genes}

We performed pathway analysis of the 179 literaturecollected CO-candidate genes (refer to Methods). This pathway enrichment analysis, conducted by applying very stringent criteria (Bonferroni multiple test correction and p-value significant threshold of 0.01 ), yielded the presence of twelve significant pathways associated with the list of our $\mathrm{CO}$ candidate genes in human (Table 3). The literature-collected candidate genes involved in multiple (at least four) pathways are presented in Additional file 6: Table S6 and marked with an asterisk in the online database.

The presence of pathways related to "cytoskeleton", "muscle development", "muscle contraction", "focal adhesion", and "insulin signaling" was previously reported in rat [7]. In addition to these pathways, our analysis showed new pathways: "cardiomyopathy" (hypertrophic and dilated), "RAS signaling", "signaling by PDGF", "signaling by EGFR", "role of MAL in Rho-mediated activation of SRF", "IGF-1 signaling pathway", and "integrin signaling". The results represent a valid example of pathway-based data mining discovery.

Table 2 Literature-collected candidate genes associated with $\mathrm{CO}$ in at least two independent literature reports

\begin{tabular}{|c|c|c|c|c|c|}
\hline Gene & $\begin{array}{l}\text { Clinical } \\
\text { syndromes }\end{array}$ & $\begin{array}{l}\text { KOs and } \\
\text { transgenes }\end{array}$ & $\begin{array}{l}\text { Overlapping } \\
\text { chromosome mutations }\end{array}$ & $\begin{array}{l}\text { Association studies } \\
\text { (number of studies) }\end{array}$ & $\begin{array}{l}\text { Expression } \\
\text { experiments }\end{array}$ \\
\hline AMH & human & mouse & & & \\
\hline AMHR2 & human & mouse & & & \\
\hline$A R$ & human & mouse & & human (2) & \\
\hline ARID5B & & mouse & & & rat \\
\hline BMP7 & & & & human & rat \\
\hline EPHA4 & & mouse & & & rat \\
\hline ESR1 & & mouse & & human (2) & \\
\hline FGFR2 & human & & human & & rat \\
\hline HOXA10 & & mouse & & human & rat \\
\hline HRAS & human & & human & & rat \\
\hline INSL3 & & mouse & & human (5), sheep, dog & \\
\hline LHCGR & human & mouse & & & \\
\hline MAP2K1 & human & & & & rat \\
\hline MSX1 & & & human & & rat \\
\hline NR5A1 & & mouse & & human & \\
\hline RXFP2 & & mouse & & human (4) & \\
\hline SOS1 & human & & & & rat \\
\hline TNNI2 & human & & human & & \\
\hline TNNT3 & human & & human & & \\
\hline WT1 & human & mouse & & & \\
\hline
\end{tabular}


Table 3 Pathway analysis of the literature-collected and network-predicted candidate genes, respectively

\begin{tabular}{|c|c|c|c|}
\hline Database & Pathway & $\begin{array}{l}\text { Bonferonni } \\
\text { p-value }\end{array}$ & Candidate genes involved in the pathway \\
\hline \multicolumn{4}{|c|}{ Literature-collected candidate genes } \\
\hline KEGG & $\begin{array}{l}\text { Regulation of actin } \\
\text { cytoskeleton }\end{array}$ & 4.70E-06 & $\begin{array}{l}\text { ACTB, BRAF, CDC42, CFL1, CHRM3, EZR, FGD1, FGF9, FGFR1, FGFR2, HRAS, ITGB1, KRAS, } \\
\text { MAP2K1, MAP2K2, MYL2, MYL9, PDGFA, PFN1, PPPICA, PPPICB, PXN, RAC1, RAF1, RHOA, } \\
\text { RRAS, SOS1 }\end{array}$ \\
\hline REACTOME & Muscle contraction & $5.39 \mathrm{E}-06$ & DES, MYH3, MYL2, MYL3, TNNI2, TNNT2, TNNT3, TPM1, TPM3, TPM4, TTN \\
\hline KEGG & Focal adhesion & $1.05 \mathrm{E}-05$ & $\begin{array}{l}\text { ACTB, BRAF, CCND1, CDC42, COL1A2, COL2A1, COL5A1, FLNA, GRB2, GSK3B, HRAS, IGF1, ILK, } \\
\text { ITGB1, MAP2K1, MYL2, MYL9, PDGFA, PPPICA, PPP1CB, PXN, RAC1, RAF1, RHOA, SOS1, THBS4 }\end{array}$ \\
\hline REACTOME & Signaling by PDGF & $3.61 \mathrm{E}-5$ & $\begin{array}{l}\text { COL1A2, COL2A1, COL5A1, GRB2, HRAS, KRAS, MAP2K1, MAP2K2, PDGFA PTPN11, RAF1, SOS1, } \\
\text { STAT3, THBS4 }\end{array}$ \\
\hline REACTOME & Signaling by insulin receptor & $7.02 \mathrm{E}-05$ & EIF4E, EIF4EBP1, GRB2, HRAS, KRAS, MAP2K1, MAP2K2, RAF1, RPS6, RPS6KB1, SOS1 \\
\hline REACTOME & Signaling by EGFR & 0.0022 & CDC42, GRB2, HRAS, KRAS, MAP2K1, MAP2K2, PTPN11, PXN, RAF1, SOS1 \\
\hline PANTHER & RAS pathway & 0.0025 & $\begin{array}{l}\text { BRAF, CDC42, GRB2, GSK3B, HRAS, KRAS, MAP2K1, MAP2K2, RAC1, RAF1, RHOA, RRAS, SOS1, } \\
\text { STAT3 }\end{array}$ \\
\hline KEGG & $\begin{array}{l}\text { Hypertrophic cardiomyopathy } \\
\text { (HCM) }\end{array}$ & 0.0035 & ACTB, DES, IGF1, ITGB1, MYH7, MYL2, MYL3, TNNT2, TPM1, TPM3, TPM4, TTN \\
\hline BIOCARTA & $\begin{array}{l}\text { Role of MAL in Rho-mediated } \\
\text { activation of SRF }\end{array}$ & 0.044 & ACTA1, CDC42, MAP2K1, MAP2K2, RAC1, RAF1, RHOA \\
\hline BIOCARTA & IGF-1 signaling & 0.0067 & FOS, GRB2, HRAS, IGF1, MAP2K1, PTPN11, RAF1, SOS1 \\
\hline PANTHER & Integrin signaling & 0.0070 & $\begin{array}{l}\text { BRAF, CDC42, COL1A2, COL2A1, COL5A1, FLNA, GRB2, HRAS, ILK, ITGB1, KRAS, MAP2K1, } \\
\text { MAP2K2, PXN, RAC1, RAF1, RHOA, RND2, RRAS, SOS1 }\end{array}$ \\
\hline KEGG & Dilated cardiomyopathy & 0.0099 & ACTB, DES, IGF1, ITGB1, MYH7, MYL2, MYL3, TNNT2, TPM1, TPM3, TPM4, TTN \\
\hline \multicolumn{4}{|c|}{ Network-predicted candidate genes } \\
\hline REACTOME & Muscle contraction & $2.71 \mathrm{E}-24$ & $\begin{array}{l}\text { ACTN2, DMD, MYBPC1, MYBPC2, MYBPC3, MYH8, MYL1, MYL4, NEB, TCAP, TMOD1, TNNC1, } \\
\text { TNNC2, TNNI1, TNNI3, TNNT1, TPM2, VIM }\end{array}$ \\
\hline KEGG & $\begin{array}{l}\text { Hypertrophic cardiomyopathy } \\
\text { (HCM) }\end{array}$ & $9.68 \mathrm{E}-6$ & ACTC1, DMD, MYBPC3, TGFB1, TGFB2, TGFB3, TNNC1, TNNI3, TPM2, \\
\hline PANTHER & TGF-beta signaling pathway & $1.07 \mathrm{E}-5$ & BMP2, LEFTY1, LEFTY2, LOC100271831, MAPK1, MAPK3, MSTN, NODAL, TGFB1, TGFB2, TGFB3 \\
\hline KEGG & Dilated cardiomyopathy & $2.35 E-5$ & ACTC1, DMD, MYBPC3, TGFB1, TGFB2, TGFB3, TNNC1, TNNI3, TPM2 \\
\hline
\end{tabular}

As an additional validation analysis, we excluded the 112 candidate genes proposed by Barthold et al. (2008) [7] from the overall candidate genes list (consisting of 179 unique human genes) and repeated the pathway analysis. Nine genes from Barthold et al. (2008) [7] were reported as $\mathrm{CO}$ candidate genes also in other studies, therefore we retained them in the analysis, so that the new list of candidate genes consisted of 79 genes. The pathway analysis of these remaining 79 candidate genes returned similar results as were obtained when using the overall 179 candidate gene list. In fact, 10 of the 12 enriched pathways were the same after excluding the discussed data from the candidate gene list. In particular, the five pathways reported by Barthold et al. (2008) [7] in rat ("cytoskeleton", "muscle development", "muscle contraction", "focal adhesion", and "insulin signaling") were all confirmed in this independent validation analysis. The main effect of the gene removal were higher, but still significant, p-values in the pathway analysis. According to these results we can infer that inclusion of the candidate genes from Barthold et al. (2008) [7] is not the reason for the substantial overlap of the five pathways identified in both studies. On the contrary, the findings proposed here are a further confirmation of the validity of the conclusions made by Barthold et al. (2008) [7].

Surprisingly, when we searched the medical literature for articles that describe pathologies where $\mathrm{CO}$, cardiomyopathy, and RAS signaling are common features, we found a perfect matching with Noonan, Cardiofaciocutaneous, LEOPARD, and Costello syndrome that all belong to the class of RASopathies [79,80]. Features of all four syndromes are different physical anomalies including concomitant presence of cardiomyopathy due to heart defects and, in males, cryptorchidism [79]. Noonan syndrome (NS) is the most common single gene cause of congenital heart disease, and NS subjects also present other features as leukemia predisposition [81]. In particular, five different mutations in RAF1 were identified in individuals with NS; four mutations causing changes in the CR2 domain of RAF1 were associated with hypertrophic cardiomyopathy (HCM), whereas mutations in 
the CR3 domain were not [82]. Additionally, PTPN11, $R A F 1$, and SOS1 mutants were identified as a major cause of Noonan syndrome, BRAF of Cardiofaciocutaneous, PTPN11 of LEOPARD, and HRAS of Costello syndrome, providing new insights into RAS regulation $[80,81]$. These genes have also been found to be mutated in patients with RASopathies having cryptorchidism in a clinical picture. In NS patients having $\mathrm{CO}$ in their clinical picture 11/14 had mutated PTPN11, 4/5 had mutated SOS1, and $1 / 2$ had mutated RAF1. $B R A F$ has been found to be mutated in $2 / 3$ patients with Cardiofaciocutaneous syndrome having CO, PTPN11 in 1/4 patients with LEOPARD having CO, and HRAS in 2/ 4 patients with Costello syndrome and CO $[80,81]$. However, the genes responsible for the remainder are unknown, and the gene pathway relations responsible for potential connections between unrelated features such as cryptorchidism and HCM in RASopathies are not clear. Therefore, we performed a network-based prediction (see next paragraph) of $\mathrm{CO}$ candidate genes by identifying the most significant first neighbors (in the human protein-protein interaction network; PPIN) of the 179 literature-collected candidates.

\section{Pathway analysis of the network-predicted candidate genes} A new cohort of 43 candidate genes (Additional file 7: Table S7) was predicted by PiNGO 1.11 [18], which is a Cytoscape plug-in (see Methods) [19]. The question we tried to address was which first-neighbor genes significantly interact with the original cohort of 179 literature-collected genes in the human PPIN. We adopted hypergeometric statistical test and Bonferroni multiple testing correction. The cohort of 43 network-predicted genes was strongly significant (Bonferroni p-value $<0.0095$ ); therefore, we consider them as additional CO candidate genes.

In order to evaluate the importance of these new candidate genes we performed the pathway analysis (Table 3), according to the same procedure already used in the previous paragraph (and described in the methods). The most intriguing evidence is the presence of significant pathways related to cardiomyopathy and muscle contraction in both sets of candidate genes (i.e. literaturecollected and network-predicted). Pathways common to both sets of candidate genes represent a confirmation of the validity and robustness of the results obtained in the first pathway analysis and regarding the hypothesis of connection between CO and cardiomyopathy, in NS. Yet, it is also a quality proof of the procedure adopted for network prediction of new candidate genes.

\section{Pathway analysis of the overall CO candidate gene list (179 literature-collected and 43 network-predicted genes)}

The first cohort of 179 literature-collected genes and the second one containing 43 network-predicted genes were condensed in a list of 222 unique genes - the overall candidate gene list. We repeated the pathway analysis on this list applying the same very stringent criteria used above (Bonferroni multiple test correction and p-value significant threshold of 0.01). The analysis suggested the presence of 12 significant pathways associated with the overall list of candidate genes in human (Table 4).

The "muscle contraction" pathway was the most significant (in absolute) with Bonferroni corrected p-value of 4.55E-33 (Figure 3A); while the "hypertrophic cardiomyopathy" was the second most significant pathway with Bonferroni corrected p-value of 1.21E-09 (Figure 3B). These results are crucial for our study because they suggest the presence of a strong genomic connection among diverse pathways associated with clinical features that seemed unrelated. To address relationship among these mechanisms we created a matrix merging the information related to the gene participation in several identified pathways. Of the $222(179+43)$ candidate genes, 172 were filtered out because they were not present in at least two of the 12 significant pathways. The resulting matrix consists of 50 candidate genes in the rows and 12 enriched pathways in the columns (Additional file 8: Table S8). The matrix values are binary: 0 indicates that the gene is not present in a pathway, whereas 1 indicates that the gene is present.

Hierarchical bi-clustering of the matrix [83], both in the rows and in the columns, was performed to detect clusters of genes which participated in common pathways, and clusters of pathways which share the same genes, respectively. The result of this analysis is provided in the Figure 4. The presence of two main groups of clusters is evident. The first group is constituted of "cardiomyopathy" (hypertrophic and dilated), "muscle contraction" and "cardiac muscle contraction" pathways. The second group is constituted of "focal adhesion", "regulation of actin cytoskeleton, "integrin signaling", "vascular smooth muscle contraction", "signaling by insulin receptor", "signaling by PDGF", "RAS pathway", and "TGF-beta signaling".

In order to further investigate the relation between the genes involved in the "cardiomyopathy" (hypertrophic and dilated), the "muscle contraction" and the "RAS pathway" and to interpret their role in creating connections between the diverse pathway modules, we searched the STRING database [20] for protein-protein interactions, selecting only the interactions with high confidence score. The outcome of this analysis is represented in Figure 5. All the 50 genes presented at least one interaction in the PPI network produced by the STRING database. This network is provided as a supplementary material (Additional file 9: Table S9).

The principal pathways involved in both, $\mathrm{CO}$ and RASopathies, are displayed on the PPIN (Figure 5), and 
Table 4 Pathway analysis of the overall candidate gene list (literature-collected and network-predicted)

\begin{tabular}{|c|c|c|c|}
\hline Database & Pathway & $\begin{array}{l}\text { Bonnferoni } \\
\text { p-value }\end{array}$ & Candidate genes involved in the pathway \\
\hline REACTOME & Muscle contraction & $4.55 \mathrm{E}-33$ & $\begin{array}{l}\text { ACTN2, DES, DMD, MYBPC1, MYBPC2, MYBPC3, MYH3, MYH8, MYL1, MYL2, MYL3, MYL4, NEB, TCAP, } \\
\text { TMOD1, TNNC1, TNNC2, TNNI1, TNNI2, TNNI3, TNNT1, TNNT2, TNNT3, TPM1, TPM2, TPM3, TPM4, TTN, } \\
\text { VIM }\end{array}$ \\
\hline KEGG & $\begin{array}{l}\text { Hypertrophic } \\
\text { cardiomyopathy (HCM) }\end{array}$ & $1.21 \mathrm{E}-9$ & $\begin{array}{l}\text { ACTB, ACTC1, DES, DMD,IGF1, ITGB1, MYBPC3, MYH7, MYL2, MYL3, TGFB1, TGFB2, TGFB3, TNNC1, } \\
\text { TNNI3, TNNT2, TPM1, TPM2, TPM3, TPM4, TTN }\end{array}$ \\
\hline KEGG & Dilated cardiomyopathy & $1.21 \mathrm{E}-8$ & $\begin{array}{l}\text { ACTB, ACTC1, DES, DMD, IGF1, ITGB1, MYBPC3, MYH7, MYL2, MYL3, TGFB1, TGFB2, TGFB3, TNNC1, } \\
\text { TNN13, TNNT2, TPM1, TPM2, TPM3, TPM4, TTN }\end{array}$ \\
\hline KEGG & Focal adhesion & 4.68E-7 & $\begin{array}{l}\text { ACTB, ACTN2, BRAF, CAV1, CCND1, CDC42, COL1A2, COL2A1, COL5A1, FLNA, GRB2, GSK3B, HRAS, } \\
\text { IGF1, IGF1R, ILK, ITGB1, MAP2K1, MAPK1, MAPK3, MYL2, MYL9, PDGFA, PPPICA, PPPICB, PRKCA, } \\
\text { PXN, RAC1, RAF1, RHOA, SOS1, THBS4 }\end{array}$ \\
\hline REACTOME & $\begin{array}{l}\text { Signaling by insulin } \\
\text { receptor }\end{array}$ & 3.83E-6 & $\begin{array}{l}\text { EIF4E, EIF4EBP1, GRB2, HRAS, KRAS, MAP2K1, MAP2K2, MAPK1, MAPK3, RAF1, RHEB, RPS6, RPS6KB1, } \\
\text { SOS1 }\end{array}$ \\
\hline KEGG & $\begin{array}{l}\text { Regulation of actin } \\
\text { cytoskeleton }\end{array}$ & $4.29 \mathrm{E}-6$ & $\begin{array}{l}\text { ACTB, ACTN2, BRAF, CDC42, CFL1, CHRM3, EZR, FGD1, FGF3, FGF9, FGFR1, FGFR2, HRAS, ITGB1, } \\
\text { KRAS, MAP2K1, MAP2K2, MAPK1, MAPK3, MYL2, MYL9, PDGFA, PFN1, PPPICA, PPP1CB, PXN, RAC1, } \\
\text { RAF1, RHOA, RRAS, SOS1 }\end{array}$ \\
\hline PANTHER & $\begin{array}{l}\text { TGF-beta signaling } \\
\text { pathway }\end{array}$ & 7.01E-6 & $\begin{array}{l}\text { AMH, AMHR2, BMP2, BMP4, BMP5, BMP7, CDC42, FOS, FOXO1, FOXP3, HRAS, KRAS, LEFTY1, LEFTY2, } \\
\text { MAPK1, MAPK3, MSTN, NODAL, RHEB, RRAS, TGFB1, TGFB2, TGFB3 }\end{array}$ \\
\hline BIOCARTA & $\begin{array}{l}\text { Integrin signaling } \\
\text { pathway }\end{array}$ & $1.35 \mathrm{E}-5$ & $\begin{array}{l}\text { ACTA1, ACTN2, CAV1, GRB2, HRAS, ITGB1, MAP2K1, MAP2K2, MAPK1, MAPK3, PXN, RAF1, RHOA, } \\
\text { SOS1 }\end{array}$ \\
\hline REACTOME & Signaling by PDGF & 7.27E-5 & $\begin{array}{l}\text { COL2A1, COL1A2, COL5A1, GRB2, HRAS, KRAS, MAP2K1, MAP2K2, MAPK1, MAPK3, PDGFA, PTPN11, } \\
\text { RAF1, SOS1, STAT3, THBS4 }\end{array}$ \\
\hline KEGG & $\begin{array}{l}\text { Cardiac muscle } \\
\text { contraction }\end{array}$ & 0.0024 & ACTC1, MYH7, MYL2, MYL3, TNNC1, TNNI3, TNNT2, TPM1, TPM2, TPM3, TPM4 \\
\hline PANTHER & RAS pathway & 0.0030 & $\begin{array}{l}\text { BRAF, CDC42, GRB2, GSK3B, HRAS, KRAS, MAP2K1, MAP2K2, MAPK1, MAPK3, RAC1, RAF1, RHOA, } \\
\text { RRAS, SOS1, STAT3 }\end{array}$ \\
\hline KEGG & $\begin{array}{l}\text { Vascular smooth } \\
\text { muscle contraction }\end{array}$ & 0.0058 & $\begin{array}{l}\text { ACTA2, BRAF, MAP2K1, MAP2K2, MAPK1, MAPK3, MYH11, MYL9, PPP1CA, PPP1CB, PRKCA, PRKCE, } \\
\text { RAF1, RHOA }\end{array}$ \\
\hline
\end{tabular}

also marked in the Figure 4 to facilitate the comparison. This figure addresses the question of the relation between the common genetic mechanisms underlying $\mathrm{CO}$ and RASopathies. Figure 5 provides a clear visualization of the overlapping pathways and of the integrated network of relations existing on proteomic level. At the best of our knowledge, this is the first time that such relation is presented, and it might help in understanding the relation between co-presence of $\mathrm{CO}$ and cardiomyopathy as clinical and apparently unrelated features in RASopathies. This fact is clarified by the layout offered in Figure 5 that reveals how the "cardiomyopathy" and the "RAS signaling" pathways are connected by a plethora of interactions with high confidence score in the STRING database. To investigate the precise type of intra- and inter- pathway interactions we suggest to mine the network that we provide in the supplementary material (Additional file 9: Table S9). Figure 5 further emphasizes how the "focal adhesion" and the "TGF-beta signaling" pathways overlap the "cardiomyopathy", the "muscle contraction" and the "RAS signaling" pathways by connecting proteins at different metabolic levels. The relevance of the "focal adhesion" pathway, as well as the importance of "cytoskeleton", "muscle development", "muscle contraction", and "insulin signaling" pathways in cryptorchidism were widely discussed [7]. However, the referred study was conducted on a rat model and all of the pathways were considered and treated separately. Here, for the first time, we proceed to an integratomic investigation of the genetic factors linked to $\mathrm{CO}$ in human. Meanwhile, we offer the holistic perspective that points out how clinical features apparently unrelated with $\mathrm{CO}$ might be generated by genetic mutation(s) which propagate at different pathway levels of the network. This propagation on different pathway-modules can justify the onset of multiple unrelated clinical features in complex diseases, such as RASopathies. The selection of 43 network-based predicted genes considered together with these last disease-related evidences are another proof that confirms the power of PPIN for association of genes with diseases [21,84].

Our results are in concordance with previous observations that alignment of human interactome with human phenome enables identification of causative genes (and networks) underlying disease families. Phenotypic overlap implies genetic overlap and human phenome can be viewed as a landscape of interrelated diseases, which reflects overlapping molecular causation [6,85-88]. In addition, it has been already shown that causative genes from syndromes that are phenotypically 


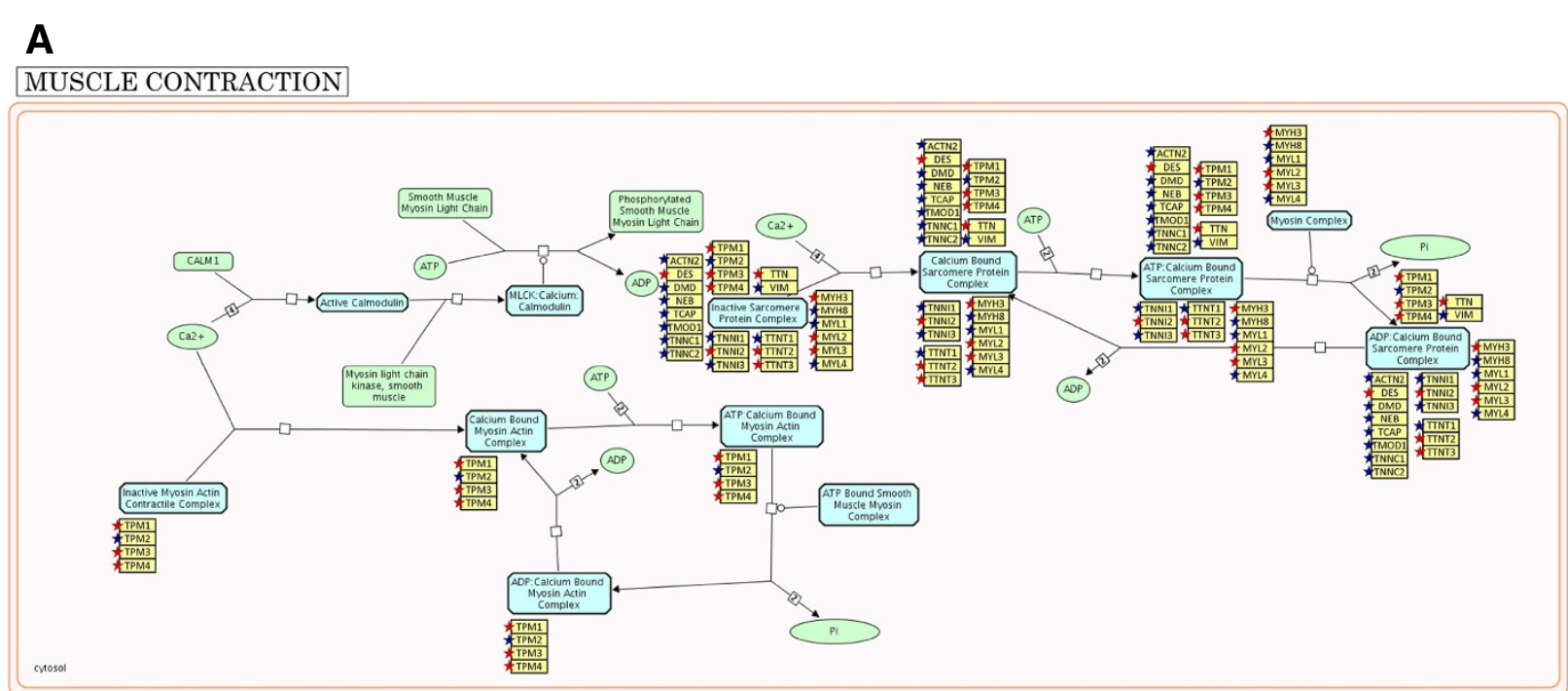

\section{B}

\section{HYPERTROPHIC CARDIOMYOPATHY (HCM)}

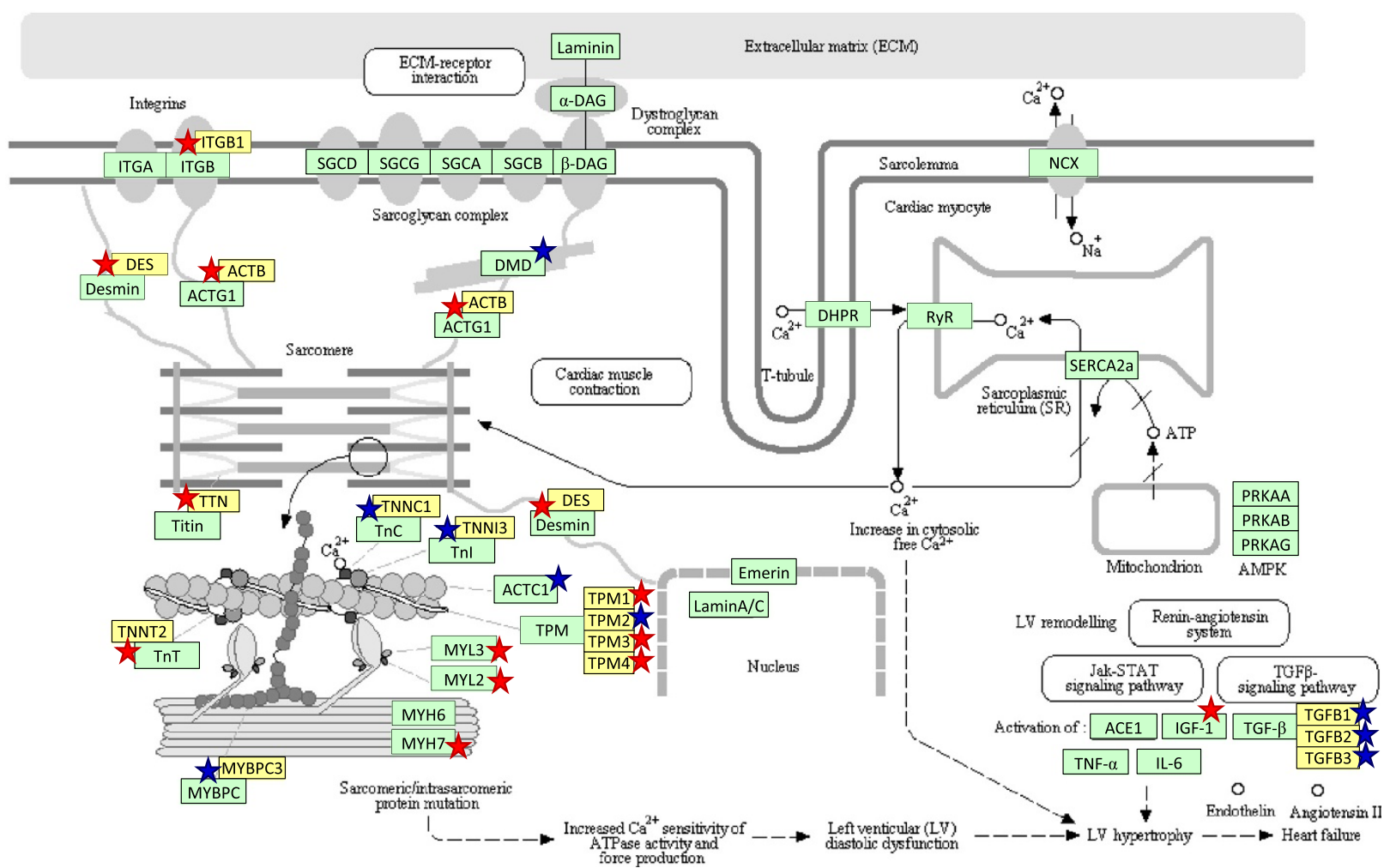

Figure 3 Pathways, containing literature-collected and network-predicted CO candidate genes. CO genes are marked with stars: red stars stand for literature-collected genes, blue stars stand for network-predicted genes. Gene names are added in yellow boxes to the original pathway images. A. Reactome pathway: Muscle contraction - human. B. KEGG pathway: Hypertrophic cardiomyopathy (HCM) - human. 


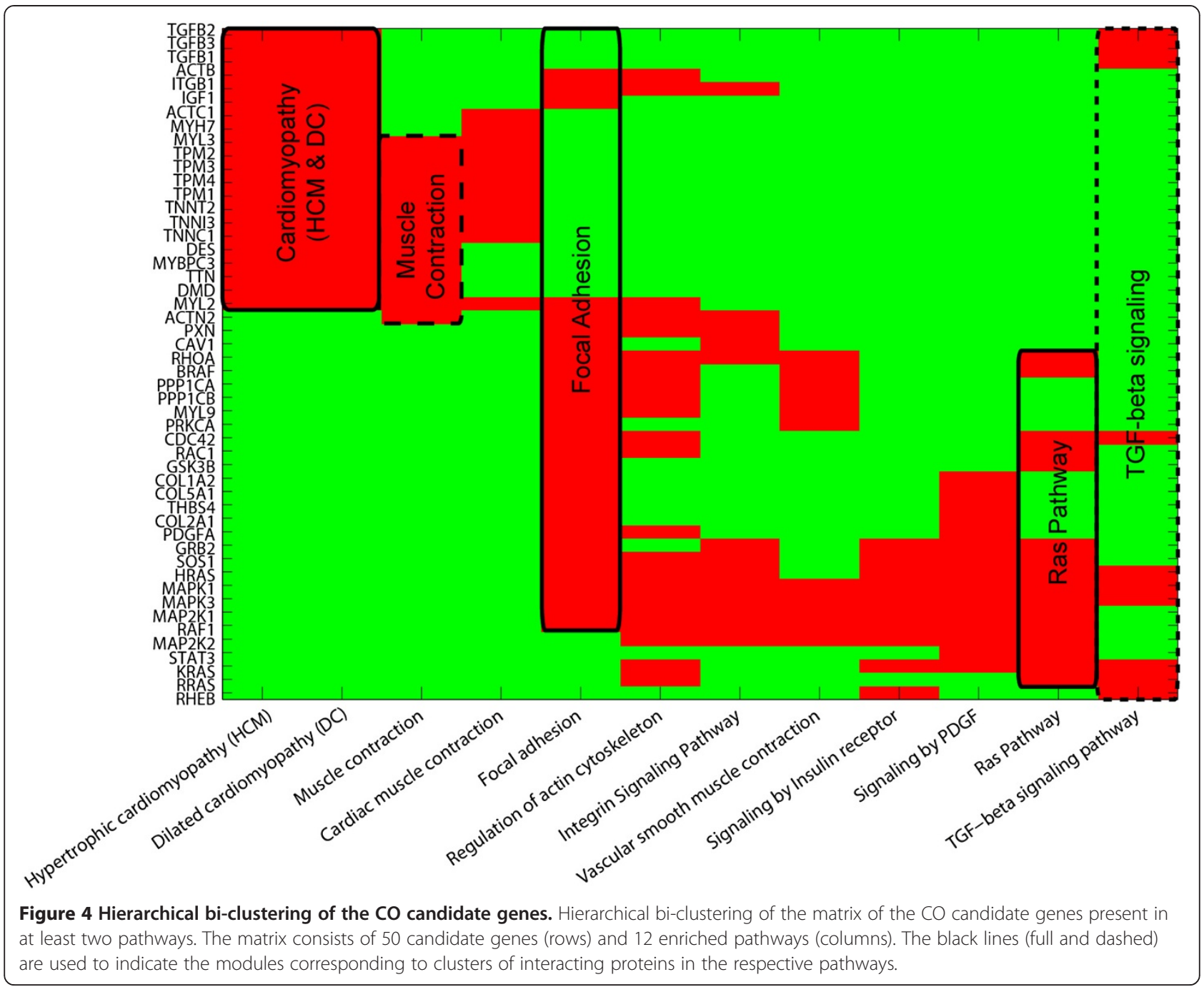

similar to a genetically uncharacterized syndrome can be used to query the gene network for functionally related candidate genes [89].

\section{Candidate gene prioritization}

Prioritization of candidate genes underlying complex traits remains one of the main challenges in molecular biology [11]. In this study we used three criteria for selecting the most promising candidate genes: 1) number of independent literature reports connecting the candidate gene with $\mathrm{CO}$ (Table 2), 2) involvement of candidate genes in enriched pathways (Table 3), and 3) position of candidate genes on the genomic map (genes positioned in regions where multiple $\mathrm{CO}$ associated data overlap were considered positional candidates) (Figure 2).

Twenty genes have been suggested as a genetic cause for $\mathrm{CO}$ in at least two independent studies (criterion 1) using different study approaches $(A M H, A M H R 2, A R$, ARID5B, BMP7, EPHA4, ESR1, FGFR2, HOXA10, HRAS, INSL3, LHCGR, MAP2K1, MSX1, NR5A1, RXFP2, SOS1,
TNNI2, TNNT3, and WT1). Among them, INSL3 has been associated with $\mathrm{CO}$ in eight, RXFP2 in five, and $A R$ in four independent studies. However, this approach should be treated with some caution because of the possible bias towards research interest into more "popular" genes. The approach will be more reliable after significant amount of unbiased genome-wide studies is available.

Considering involvement in enriched pathways (criterion 2), the most promising candidates would be HRAS, MAP2K1, MAP2K2, GRB2, RAF1 and SOS1, which are all involved in seven or more enriched pathways. For the literature-collected candidate genes involved in multiple (four or more) CO-enriched pathways we assembled genetic information relevant for further functional analyses: assignment to corresponding biological pathways, genetic variability, and putative presence of polymorphic microRNA (miRNA) target sites (Additional file 6: Table S6). The importance of small non-coding RNAs (ncRNAs) in gene regulation and pathogenesis of the 


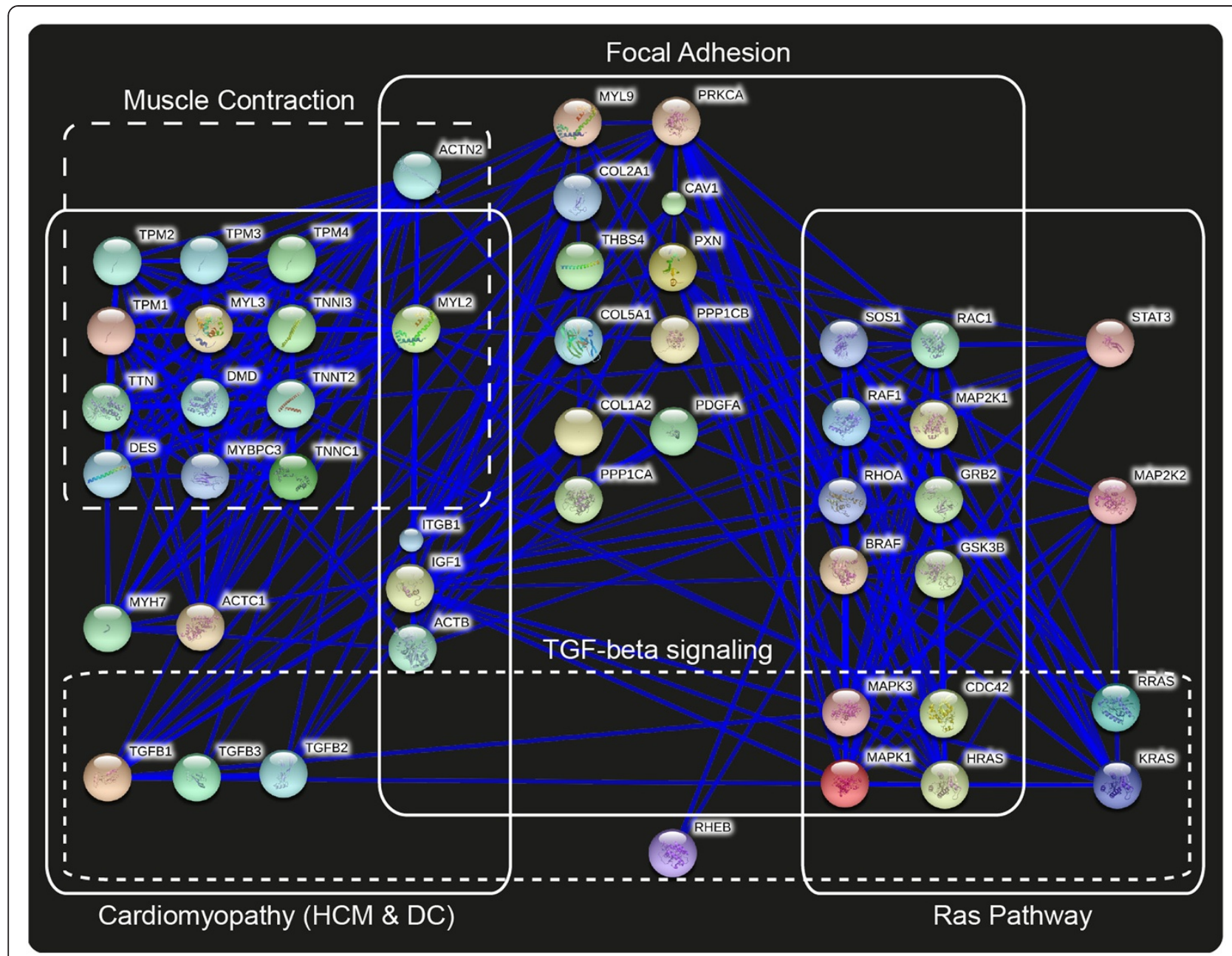

Figure 5 String protein-protein interaction network (PPIN) of the CO candidate genes. PPIN is obtained from the 50 CO candidate genes interacting in the STRING database. The lines (full and dashed) delimit the presence of the diverse overlapped protein-pathway-modules. The same line is used in the Figure 4 to indicate the modules corresponding to clusters of interacting proteins in the respective pathways.

diseases, including reduced fertility, is today evident [90]. However, to our knowledge, there are no literature reports associating ncRNAs or epigenetic factors with $\mathrm{CO}$.

The most promising candidates meeting both suggested criteria (1 and 2) are FGFR2 (reported in two $\mathrm{CO}$-associated studies/ involved in one CO-associated pathway), HRAS (3/8), MAP2K1 (2/9), and SOS1 (2/5). Additionally, TNNI2 and TNNT3 are reported in the literature (once each), involved in one $\mathrm{CO}$ enriched pathway (i.e. "muscle contraction"), and positioned in a region overlapping chromosomal mutation.

Genomic regions involved in the chromosome mutations on chromosomes $2,4,8,9,11$, and X overlapped with 14 candidate genes suggested as positional candidates (criterion 3): CAPG, MSX1, E2F5, PTCH1, BICD2, RPS6, FGFR2, HRAS, PAX6, WT1, TNNI2, $T N N 3$, FLNA, and MECP2. Additionally, three networkpredicted candidate genes, FHL2, TMOD1 and MYBPC3 overlapped with chromosomal mutations. Considering suggested prioritization criteria, HRAS gene meets all of them.

Reliability of such methodologically different approaches is not always comparable (for example, data from genome-wide expression experiments is much less validated than syndromic or transgenic data); therefore, ranking candidate genes based only on a number of different reports/approaches is not always feasible. However, less validated data may also be of high biological relevance and should not be discarded for hypothesis-driven approaches. To increase reliability of the collected heterogeneous data we tested in silico how candidate genes interact at the proteomic level. Although integratomic approaches are only partially established yet and have several drawbacks, including already mentioned heterogeneity of input data, we believe that such approaches are a reasonable and at the moment among the most promising 
ways for hypothesis generation, which should be further experimentally validated in animal and/or human populations. Similar integratomics approach was already used for identification of candidate loci for mammary gland associated phenotypes [8], male infertility [9], and obesity $[10,91]$, and could be adapted to any other complex trait.

\section{Conclusions}

In this study we present an overview of $\mathrm{CO}$ associated candidate regions/genes and suggest pathways potentially involved in the pathogenesis of the disease. The integrative, comparative-genomics approach, and in silico analyses of the collected data aim to help solving the problem of fragmented and often contradictory data extracted from different methodologically focused studies. The protein-protein interactions analysis revealed the most relevant pathways associated with $\mathrm{CO}$ candidate gene list and enabled us to suggest additional candidate genes based on network prediction. Described systems biology approach will contribute to a better understanding of genetic causes for cryptorchidism and provides possible example how integration and linking of complex traits related data can be used for hypothesis generation. Publicly available online $\mathrm{CO}$ gene atlas and data entry option will allow researcher to enter, browse, and visualize $\mathrm{CO}$ associated data. The proposed network-based approach elucidates co-presence of similar pathogenetic mechanisms underlying diverse clinical syndromes/defects and could be of a great importance in research in the field of molecular syndromology. This approach has also a potential to be used for future development of diagnostic, prognostic, and therapeutic markers. The developed integratomics approach can be extrapolated to study genetic background of any other complex traits/diseases and to generate hypothesis for downstream experimental validation.

\section{Additional files}

Additional file 1: Table S1. Chromosomal abnormalities and CNVs associated with cryptorchidism.

Additional file 2: Table S2. Selected clinical syndromes that feature CO in their clinical picture.

Additional file 3: Table S3. Transgenic and knock-out murine models that display cryptorchid phenotype.

Additional file 4: Table S4. Genes tested for association with CO.

Additional file 5: Table S5. Genes with expression patterns associated with $\mathrm{CO}$. Genes with expression patterns associated with $\mathrm{CO}$ in rat (adapted from [7]) and genomic location of their human orthologs.

Additional file 6: Table S6. The literature collected candidate genes involved in multiple (four or more) CO-associated pathways.

Additional file 7: Table S7. Forty-three network-predicted CO-associated candidate genes.
Additional file 8: Table S8. Protein network information matrix for candidate genes. Protein network information matrix for candidate genes involved in at least two pathways significant for literature-collected and network-predicted candidate genes. The matrix consists of 50 rows (each row corresponds to a different gene involved in at least two pathways) and 12 columns (each column corresponds to a different pathway), where 0 indicates that the gene is not present in a pathway and 1 indicates that the gene is present in it.

Additional file 9: Table S9. STRING network data: list of protein network interactions present in STRING with high confidence score.

\section{Competing interests}

The authors declare that they have no competing interests.

\section{Authors' contributions}

CVC performed pathway and PPIN analyses. JO, TK, and MZ performed the data mining and established the database. TK, JO, and CVC interpreted the results and drafted the manuscript. $M Z$ developed web-based interactive visualization tool. PD and TR provided feedback on the initial draft and contributed to the final editing of the manuscript. All authors have read and approved the final manuscript.

\section{Acknowledgements}

This work was supported by the Slovenian Research Agency (ARRS) through the Research programme Comparative genomics and genome biodiversity (P4-0220). C.V.C. received financial support from the Italian Inter-polytechnic School of Doctorate (SIPD) and from the King Abdullah University of Science and Technology.

\section{Author details}

${ }^{1}$ Integrative Systems Biology Laboratory, Biological and Environmental Sciences and Engineering Division, Computer, Electrical and Mathematical Sciences and Engineering Division, Computational Bioscience Research Center, King Abdullah University for Science and Technology (KAUST), Thuwal, Saudi Arabia. ${ }^{2}$ Department of Mechanics, Politecnico di Torino, Turin, Italy. ${ }^{3}$ Proteome Biochemistry Unit, San Raffaele Scientific Institute, Milan, Italy. ${ }^{4}$ Department of Animal Science, Biotechnical Faculty, University of Ljubljana, Domzale, Slovenia.

Received: 14 February 2012 Accepted: 6 February 2013

Published: 14 February 2013

\section{References}

1. Dovc P, Kunej T, Williams GA: Genetics and genomics of reproductive disorders. In Reproductive Genomics of Domestic Animals. 1st edition. Edited by Jiang Z, Ott TL. Oxford, UK: Wiley-Blackwell; 2010:67-97.

2. Amann RP, Veeramachaneni DNR: Cryptorchidism in common eutherian mammals. Reproduction 2007, 133(3):541-561.

3. Foresta C, Zuccarello D, Garolla A, Ferlin A: Role of hormones, genes, and environment in human cryptorchidism. Endocr Rev 2008, 29(5):560-580.

4. Barthold JS: Undescended testis: current theories of etiology. Curr Opin Urol 2008, 18(4):395-400.

5. Mortell A, Montedonico S, Puri P: Animal models in pediatric surgery. Pediatr Surg Int 2006, 22(2):111-128.

6. Oti M, Huynen MA, Brunner HG: Phenome connections. Trends Genet 2008 24(3):103-106.

7. Barthold JS, McCahan SM, Singh AV, Knudsen TB, Si X, Campion L, Akins RE: Altered expression of muscle- and cytoskeleton-related genes in a rat strain with inherited cryptorchidism. J Androl 2008, 29(3):352-366.

8. Ogorevc J, Kunej T, Razpet A, Dovc P: Database of cattle candidate genes and genetic markers for milk production and mastitis. Anim Genet 2009, 40(6):832-851.

9. Ogorevc J, Dovc P, Kunej T: Comparative genomics approach to identify candidate genetic loci for male fertility. Reprod Domest Anim 2011, 46(2):229-239.

10. Kunej T, Jevsinek Skok D, Zorc M, Ogrinc A, Michal JJ, Kovac M, Jiang Z: Obesity gene atlas in mammals. J Genomics 2012, 1:45-55.

11. Moreau Y, Tranchevent LC: Computational tools for prioritizing candidate genes: boosting disease gene discovery. Nat Rev Genet 2012, 13(8):523-536. 
12. Zorc M, Jevsinek Skok D, Godnic I, Calin GA, Horvat S, Jiang Z, Dovc P, Kunej T: Catalog of MicroRNA Seed Polymorphisms in Vertebrates. PLoS One 2012, 7(1):e30737.

13. da Huang W, Sherman BT, Tan Q, Kir J, Liu D, Bryant D, Guo Y, Stephens R, Baseler MW, Lane HC, et al: DAVID Bioinformatics Resources: expanded annotation database and novel algorithms to better extract biology from large gene lists. Nucleic Acids Res 2007, 35(Web Server issue): W169-W175.

14. Razick S, Magklaras G, Donaldson IM: iReflndex: a consolidated protein interaction database with provenance. BMC Bioinforma 2008, 9:405.

15. Chuang HY, Lee E, Liu YT, Lee D, Ideker T: Network-based classification of breast cancer metastasis. Mol Syst Biol 2007, 3:140.

16. Ravasi T, Cannistraci CV, Suzuki H, Katayama S, Bajic VB, Tan K, Akalin A, Schmeie $\mathrm{S}$, Kanamori-Katayama M, Bertin N, et al: An Atlas of Combinatorial Transcriptional Regulation in Mouse and Man. Cell 2010, 140(5):744-752.

17. Kamburov A, Wierling C, Lehrach H, Herwig R: ConsensusPathDB-a database for integrating human functional interaction networks. Nucleic Acids Res 2009, 37(Database issue):D623-D628.

18. Smoot M, Ono K, Ideker T, Maere S: PiNGO: a Cytoscape plugin to find candidate genes in biological networks. Bioinformatics 2011, 27(7):1030-1031.

19. Smoot ME, Ono K, Ruscheinski J, Wang PL, Ideker T: Cytoscape 2.8: new features for data integration and network visualization. Bioinformatics 2011, 27(3):431-432.

20. Szklarczyk D, Franceschini A, Kuhn M, Simonovic M, Roth A, Minguez $P$, Doerks T, Stark M, Muller J, Bork P, et al: The STRING database in 2011: functional interaction networks of proteins, globally integrated and scored. Nucleic Acids Res 2011, 39(Database issue):D561-D568.

21. Hiard S, Charlier C, Coppieters W, Georges M, Baurain D: Patrocles: a database of polymorphic miRNA-mediated gene regulation in vertebrates. Nucleic Acids Res 2010, 38(Database issue):D640-D651.

22. Miyake $Y$, Kaneda $Y$ : A new type of Robertsonian translocation (1/26) in a bull with unilateral cryptorchidism, probably occurring de novo. Nihon juigaku zasshi J Vet Sci 1987, 49(6):1015-1019.

23. Sasagawa I, Nakada T, Ishigooka M, Sawamura T, Adachi Y, Hashimoto T: Chromosomal anomalies in cryptorchidism. Int Urol Nephrol 1996, 28(1):99-102.

24. Ogata T, Muroya K, Matsuo N, Hata J, Fukushima Y, Suzuki Y: Impaired male sex development in an infant with molecularly defined partial 9p monosomy: implication for a testis forming gene(s) on 9p. J Med Genet 1997, 34(4):331-334.

25. Suzuki Y, Sasagawa I, Nakada T, Onmura Y: Bilateral cryptorchidism associated with terminal deletion of 10q. Urol Int 1998, 61(3):186-187.

26. Goldschmidt B, El-Jaick KB, Souza LM, Carvalho ECQ, Moura VLS, Benevides Filho IM: Cryptorchidism associated with 78, XY/79, XXY mosaicism in dog. Israel J Vet Med 2001, 56:56-58

27. Moreno-Garcia M, Miranda EB: Chromosomal anomalies in cryptorchidism and hypospadias. J Urol 2002, 168(5):2170-2172. discussion 2172.

28. Prabhakara K, Angalena R, Ramadevi AR: Familial (9;11)(p22;p15.5)pat translocation and XX sex reversal in a phenotypic boy with cryptorchidism and delayed development. Genetic counseling (Geneva, Switzerland) 2004, 15(1):37-41.

29. Brito L, Sertich PL, Durkin K, Chowdhary BP, Turner RM, Greene LM, McDonnell S: Autosomic 27 Trisomy in a Standardbred Colt. J Equine Vet Sci 2008, 28(7):431-436.

30. Tartaglia N, Davis S, Hench A, Nimishakavi S, Beauregard R, Reynolds A, Fenton L, Albrecht L, Ross J, Visootsak J, et al: A new look at XXYY syndrome: medical and psychological features. Am J Med Genet A 2008, 146A(12):1509-1522.

31. van der Veken LT, Dieleman MM, Douben $H$, van de Brug JC, van de Graaf R, Hoogeboom AJ, Poddighe PJ, de Klein A: Low grade mosaic for a complex supernumerary ring chromosome 18 in an adult patient with multiple congenital anomalies. Mol Cytogenet 2010, 3:13.

32. Niyazov DM, Nawaz Z, Justice AN, Toriello HV, Martin CL, Adam MP: Genotype/phenotype correlations in two patients with 12q subtelomere deletions. Am J Med Genet A 2007, 143A(22):2700-2705.

33. Melis D, Genesio R, Boemio P, Del Giudice E, Cappuccio G, Mormile A Ronga V, Conti A, Imperati F, Nitsch L, et al: Clinical description of a patient carrying the smallest reported deletion involving 10p14 region. Am J Med Genet A 2012, 158A(4):832-835.

34. Tannour-Louet M, Han S, Corbett ST, Louet JF, Yatsenko S, Meyers L, Shaw CA, Kang SH, Cheung SW, Lamb DJ: Identification of de novo copy number variants associated with human disorders of sexual development. PLoS One 2010, 5(10):e15392.
35. Peltonen L, Perola M, Naukkarinen J, Palotie A: Lessons from studying monogenic disease for common disease. Hum Mol Genet 2006, 15:R67-R74. Spec No 1.

36. Gianotten J, van der Veen F, Alders M, Leschot NJ, Tanck MW, Land JA, Kremer JA, Hoefsloot LH, Mannens MM, Lombardi MP, et al: Chromosomal region 11 p15 is associated with male factor subfertility. Mol Hum Reprod 2003, 9(10):587-592.

37. Klonisch T, Fowler PA, Hombach-Klonisch S: Molecular and genetic regulation of testis descent and external genitalia development. Dev Biol 2004, 270(1):1-18.

38. Kreidberg JA, Sariola H, Loring JM, Maeda M, Pelletier J, Housman D, Jaenisch R: WT-1 IS REQUIRED FOR EARLY KIDNEY DEVELOPMENT. Cell 1993, 74(4):679-691.

39. Ikadai H, Ajisawa C, Taya K, Imamichi T: Suprainguinal ectopic scrota of TS inbred rats. J Reprod Fertil 1988, 84(2):701-707.

40. Li X, Nokkala E, Yan W, Streng T, Saarinen N, Warri A, Huhtaniemi I, Santti R, Makela S, Poutanen M: Altered structure and function of reproductive organs in transgenic male mice overexpressing human aromatase. Endocrinology 2001, 142(6):2435-2442

41. Caron P, Imbeaud S, Bennet A, Plantavid M, Camerino G, Rochiccioli P: Combined hypothalamic-pituitary-gonadal defect in a hypogonadic man with a novel mutation in the DAX-1 gene. J Clin Endocrinol Metab 1999, 84(10):3563-3569.

42. Donaldson KM, Tong SY, Washburn T, Lubahn DB, Eddy EM, Hutson JM, Korach KS: Morphometric study of the gubernaculum in male estrogen receptor mutant mice. J Androl 1996, 17(2):91-95.

43. Gorlov IP, Kamat A, Bogatcheva NV, Jones E, Lamb DJ, Truong A, Bishop CE, McElreavey K, Agoulnik Al: Mutations of the GREAT gene cause cryptorchidism. Hum Mol Genet 2002, 11(19):2309-2318.

44. Canto P, Escudero I, Soderlund D, Nishimura E, Carranza-Lira S, Gutierrez J, Nava A, Mendez JP: A novel mutation of the insulin-like 3 gene in patients with cryptorchidism. J Hum Genet 2003, 48(2):86-90.

45. Ferlin A, Garolla A, Bettella A, Bartoloni L, Vinanzi C, Roverato A, Foresta C: Androgen receptor gene CAG and GGC repeat lengths in cryptorchidism. Eur J Endocrinol 2005, 152(3):419-425.

46. Yoshida R, Fukami M, Sasagawa I, Hasegawa T, Kamatani N, Ogata T: Association of cryptorchidism with a specific haplotype of the estrogen receptor alpha gene: implication for the susceptibility to estrogenic environmental endocrine disruptors. J Clin Endocrinol Metab 2005, 90(8):4716-4721.

47. Ferlin A, Bogatcheva NV, Gianesello L, Pepe A, Vinanzi C, Agoulnik Al, Foresta C: Insulin-like factor 3 gene mutations in testicular dysgenesis syndrome: clinical and functional characterization. Mol Hum Reprod 2006, 12(6):401-406.

48. Silva-Ramos M, Oliveira JM, Cabeda JM, Reis A, Soares J, Pimenta A: The CAG repeat within the androgen receptor gene and its relationship to cryptorchidism. Int Braz J Urol 2006, 32(3):330-334. discussion 335

49. Wada Y, Okada M, Fukami M, Sasagawa I, Ogata T: Association of cryptorchidism with Gly146Ala polymorphism in the gene for steroidogenic factor-1. Fertil Steril 2006, 85(3):787-790.

50. Bogatcheva NV, Ferlin A, Feng S, Truong A, Gianesello L, Foresta C, Agoulnik Al: T222P mutation of the insulin-like 3 hormone receptor LGR8 is associated with testicular maldescent and hinders receptor expression on the cell surface membrane. Am J Physiol Endocrinol Metab 2007, 292(1):E138-E144

51. El Houate B, Rouba H, Sibai H, Barakat A, Chafik A, Chadli el B, Imken L, Bogatcheva NV, Feng S, Agoulnik Al, et al: Novel mutations involving the INSL3 gene associated with cryptorchidism. J Urol 2007, 177(5):1947-1951.

52. Yamazawa K, Wada Y, Sasagawa I, Aoki K, Ueoka K, Ogata T: Mutation and polymorphism analyses of INSL3 and LGR8/GREAT in 62 Japanese patients with cryptorchidism. Horm Res 2007, 67(2):73-76.

53. Wang Y, Barthold J, Figueroa E, Gonzalez R, Noh PH, Wang M, Manson J: Analysis of five single nucleotide polymorphisms in the ESR1 gene in cryptorchidism. Birth Defects Res A Clin Mol Teratol 2008, 82(6):482-485.

54. Harris RM, Finlayson C, Weiss J, Fisher L, Hurley L, Barrett T, Emge D, Bathgate RA, Agoulnik Al, Jameson JL: A missense mutation in LRR8 of RXFP2 is associated with cryptorchidism. Mamm Genome 2010, 21(9-10):442-449.

55. Tang KF, Zheng JZ, Xing JP: Molecular analysis of SNP12 in estrogen receptor alpha gene in hypospadiac or cryptorchid patients from Northwestern China. Urol Int 2011, 87(3):359-362.

56. Feng S, Ferlin A, Truong A, Bathgate R, Wade JD, Corbett S, Han S, TannourLouet M, Lamb DJ, Foresta C, et al: INSL3/RXFP2 signaling in testicular descent. Ann N Y Acad Sci 2009, 1160:197-204. 
57. Dalgaard MD, Weinhold N, Edsgard D, Silver JD, Pers TH, Nielsen JE, Jorgensen N, Juul A, Gerds TA, Giwercman A, et al: A genome-wide association study of men with symptoms of testicular dysgenesis syndrome and its network biology interpretation. J Med Genet 2012, 49(1):58-65

58. Kolon TF, Wiener JS, Lewitton M, Roth DR, Gonzales ET Jr, Lamb DJ: Analysis of homeobox gene HOXA10 mutations in cryptorchidism. J Urol 1999, 161(1):275-280

59. Teles MG, Trarbach EB, Noel SD, Guerra-Junior G, Jorge A, Beneduzzi D, Bianco SD, Mukherjee A, Baptista MT, Costa EM, et al: A novel homozygous splice acceptor site mutation of KISS1R in two siblings with normosmic isolated hypogonadotropic hypogonadism. Eur J Endocrinol 2010, 163(1):29-34.

60. Williams GA, Ott TL, Michal JJ, Gaskins $C T$, Wright RW Jr, Daniels TF, Jiang Z Development of a model for mapping cryptorchidism in sheep and initial evidence for association of INSL3 with the defect. Anim Genet 2007, 38(2):189-191

61. Cassata R, lannuzzi A, Parma P, De Lorenzi L, Peretti V, Perucatti A, lannuzzi L, Di Meo GP: Clinical, cytogenetic and molecular evaluation in a dog with bilateral cryptorchidism and hypospadias. Cytogenet Genome Res 2008, 120(1-2):140-143.

62. Zhao X, Du ZQ, Rothschild MF: An association study of 20 candidate genes with cryptorchidism in Siberian Husky dogs. J Anim Breed Genet 2010, 127(4):327-331

63. Galan JJ, Guarducci E, Nuti F, Gonzalez A, Ruiz M, Ruiz A, Krausz C: Molecular analysis of estrogen receptor alpha gene AGATA haplotype and SNP12 in European populations: potential protective effect for cryptorchidism and lack of association with male infertility. Hum Reprod 2007, 22(2):444-449.

64. Pathirana IN, Tanaka K, Kawate N, Tsuji M, Kida K, Hatoya S, Inaba T, Tamada $\mathrm{H}$ : Analysis of single nucleotide polymorphisms in the $3^{\prime}$ region of the estrogen receptor 1 gene in normal and cryptorchid Miniature Dachshunds and Chihuahuas. J Reprod Dev 2010, 56(4):405-410.

65. Lo Giacco D, Ars E, Bassas L, Galan JJ, Rajmil O, Ruiz P, Caffaratti J, Guarducci $E$, Ruiz-Castane E, Krausz C: ESR1 promoter polymorphism is not associated with nonsyndromic cryptorchidism. Fertil Steril 2011, 95(1):369-371. 371 e361-362.

66. Krausz C, Quintana-Murci L, Fellous M, Siffroi JP, McElreavey K: Absence of mutations involving the INSL3 gene in human idiopathic cryptorchidism. Mol Hum Reprod 2000, 6(4):298-302.

67. Takahashi I, Takahashi T, Komatsu M, Matsuda J, Takada G: Ala/Thr60 variant of the Leydig insulin-like hormone is not associated with cryptorchidism in the Japanese population. Pediatr Int 2001, 43(3):256-258

68. Baker LA, Nef S, Nguyen MT, Stapleton R, Nordenskjold A, Pohl H, Parada LF: The insulin-3 gene: lack of a genetic basis for human cryptorchidism. J Urol 2002, 167(6):2534-2537.

69. Bertini V, Bertelloni S, Valetto A, Lala R, Foresta C, Simi P: Homeobox HOXA10 gene analysis in cryptorchidism. J Pediatr Endocrinol Metab 2004, 17(1):41-45

70. Nuti F, Marinari E, Erdei E, El-Hamshari M, Echavarria MG, Ars E, Balercia G, Merksz M, Giachini C, Shaeer KZ, et al: The leucine-rich repeat-containing $\mathrm{G}$ protein-coupled receptor 8 gene T222P mutation does not cause cryptorchidism. J Clin Endocrinol Metab 2008, 93(3):1072-1076.

71. Simoni M, Tuttelmann F, Michel C, Bockenfeld Y, Nieschlag E, Gromoll J: Polymorphisms of the luteinizing hormone/chorionic gonadotropin receptor gene: association with maldescended testes and male infertility. Pharmacogenet Genomics 2008, 18(3):193-200.

72. Kunej T, Zorn B, Peterlin B: Y chromosome microdeletions in infertile men with cryptorchidism. Fertil Steril 2003, 79(Suppl 3):1559-1565.

73. Bor P, Hindkjaer J, Kolvraa S, Rossen P, von der Maase H, Jorgensen TM, Sorensen VT, Eiberg H, Ingerslev HJ: Screening for $Y$ microdeletions in men with testicular cancer and undescended testis. J Assist Reprod Genet 2006, 23(1):41-45.

74. Gurbuz N, Ozbay B, Aras B, Tasci Al: Do microdeletions in the AZF region of the $\mathrm{Y}$ chromosome accompany cryptorchidism in Turkish children? Int Urol Nephrol 2008, 40(3):577-581.

75. Hejmej A, Gorazd M, Kosiniak-Kamysz K, Wiszniewska B, Sadowska J, Bilinska $B$ : Expression of aromatase and oestrogen receptors in reproductive tissues of the stallion and a single cryptorchid visualised by means of immunohistochemistry. Domest Anim Endocrinol 2005, 29(3):534-547.
76. Nguyen MT, Delaney DP, Kolon TF: Gene expression alterations in cryptorchid males using spermatozoal microarray analysis. Fertil Steril 2009, 92(1):182-187.

77. Hutson JM, Watts LM, Farmer PJ: Congenital undescended testes in neonatal pigs and the effect of exogenous calcitonin gene-related peptide. J Urol 1998, 159(3):1025-1028.

78. Zuccarello D, Morini E, Douzgou S, Ferlin A, Pizzuti A, Salpietro DC, Foresta C, Dallapiccola B: Preliminary data suggest that mutations in the CgRP pathway are not involved in human sporadic cryptorchidism. J Endocrinol Invest 2004, 27(8):760-764.

79. Bertola DR, Pereira AC, Passetti F, de Oliveira PS, Messiaen L, Gelb BD, Kim CA, Krieger JE: Neurofibromatosis-Noonan syndrome: molecular evidence of the concurrence of both disorders in a patient. Am J Med Genet $A$ 2005, 136(3):242-245.

80. Digilio MC, Lepri F, Baban A, Dentici ML, Versacci P, Capolino R, Ferese R, De Luca A, Tartaglia M, Marino B, et al: RASopathies: Clinical Diagnosis in the First Year of Life. Molecular syndromology 2011, 1(6):282-289.

81. Roberts AE, Araki T, Swanson KD, Montgomery KT, Schiripo TA, Joshi VA, Li L, Yassin Y, Tamburino AM, Neel BG, et al: Germline gain-of-function mutations in SOS1 cause Noonan syndrome. Nat Genet 2007, 39(1):70-74.

82. Razzaque MA, Nishizawa T, Komoike Y, Yagi H, Furutani M, Amo R, Kamisago M, Momma K, Katayama H, Nakagawa M, et al: Germline gain-of-function mutations in RAF1 cause Noonan syndrome. Nat Genet 2007, 39(8):1013-1017.

83. Cannistraci CV, Ravasi T, Montevecchi FM, Ideker T, Alessio M: Nonlinear dimension reduction and clustering by Minimum Curvilinearity unfold neuropathic pain and tissue embryological classes. Bioinformatics 2010, 26(18):i531-i539.

84. Navlakha S, Kingsford C: The power of protein interaction networks for associating genes with diseases. Bioinformatics (Oxford, England) 2010, 26:1057-1063. England.

85. Rzhetsky $A$, Wajngurt $D$, Park N, Zheng T: Probing genetic overlap among complex human phenotypes. P Natl Acad Sci USA 2007, 104(28):1169411699.

86. Wu X, Jiang R, Zhang MQ, Li S: Network-based global inference of human disease genes. Mol Syst Biol 2008, 4:189.

87. Wu X, Liu Q, Jiang R: Align human interactome with phenome to identify causative genes and networks underlying disease families. Bioinformatics 2009, 25(1):98-104.

88. Loscalzo J, Barabasi AL: Systems biology and the future of medicine. Wiley Interdiscip Rev Syst Biol Med 2011, 3(6):619-627.

89. Oti M, Brunner HG: The modular nature of genetic diseases. Clin Genet 2007, 71(1):1-11.

90. Ogorevc J, Dovc P, Kunej T: Polymorphisms in microRNA targets: a source of new molecular markers for male reproduction. Asian J Androl 2011, 13(3):505-508.

91. Kunej T, Skok DJ, Horvat S, Dovc P, Jiang Z: The glypican 3-hosted murine mir717 gene: sequence conservation, seed region polymorphisms and putative targets. Int J Biol Sci 2010, 6(7):769-772.

doi:10.1186/1755-8794-6-5

Cite this article as: Cannistraci et al:: Pivotal role of the musclecontraction pathway in cryptorchidism and evidence for genomic connections with cardiomyopathy pathways in RASopathies. BMC Medical Genomics 2013 6:5.

\section{Submit your next manuscript to BioMed Central and take full advantage of:}

- Convenient online submission

- Thorough peer review

- No space constraints or color figure charges

- Immediate publication on acceptance

- Inclusion in PubMed, CAS, Scopus and Google Scholar

- Research which is freely available for redistribution 